\title{
AUGMENTED REALITY-BASED STUDENT WORKSHEET TO STIMULATE STUDENTS' CRITICAL THINKING SKILLS
}

\author{
Romy Desmara Fendi ${ }^{1 *}$, Agus Suyatna ${ }^{2}$, Abdurrahman ${ }^{3}$ \\ ${ }^{1,2,3}$ Department of Physics Education, Postgraduate Program, Universitas Lampung, Indonesia \\ *Corresponding author: romy.rdf88@gmail.com
}

\begin{tabular}{|c|c|}
\hline Article Info & ABSTRACT \\
\hline Article History: & Critical thinking skill which is one of the important abilities in the $21 \mathrm{st}$ \\
\hline Received: June 05, 2021 & century is important to be trained in learning. The purpose of this research \\
\hline Accepted: July 17, 2021 & is valid, practical, and effective to stimulate students' critical thinking. \\
\hline Published: July 31, 2021 & $\begin{array}{l}\text { The development model used the ADDIE model which consists of } \\
\text { analysis, design, development, implementation, and evaluation steps. The }\end{array}$ \\
\hline & $\begin{array}{l}\text { product developed was tested for validation, practicality test, and } \\
\text { effectiveness test. The results of the validity test obtained a value of }\end{array}$ \\
\hline Augmented reality (AR) & $81.80 \%$ with a valid category. The results of the practicality test obtained \\
\hline Critical thinking & a percentage of $80.85 \%$ with good criteria. The results of the effectiveness \\
\hline Student activity sheet & $\begin{array}{l}\text { test showed an N-Gain value of } 0.67 \text { with the moderately effective } \\
\text { category. From the average pretest and posttest scores, it can be seen that } \\
\text { the posttest average score increased by } 39.04 \text { which indicates that the use } \\
\text { of AR-based worksheets can improve students' critical thinking. It can be } \\
\text { concluded that AR-based worksheets on the concept of dynamic } \\
\text { electricity developed are valid, practical, and effective to stimulate } \\
\text { students' critical thinking. }\end{array}$ \\
\hline
\end{tabular}

\section{LEMBAR KEGIATAN SISWA BERBASIS AUGMENTED REALITY UNTUK MENSTIMULUS BERPIKIR KRITIS SISWA}

\begin{tabular}{|c|c|}
\hline & ABSTRAK \\
\hline $\begin{array}{l}\text { Kata Kunci: } \\
\text { Augmented reality }(A R) \\
\text { Berpikir kritis } \\
\text { lembar kerja siswa }\end{array}$ & $\begin{array}{l}\text { Keterampilan berpikir kritis yang merupakan salah satu kemampuan } \\
\text { penting di abad } 21 \text { penting untuk dilatih dalam pembelajaran. Penelitian } \\
\text { ini bertujuan untuk mengembangkan LKS berbasis AR materi kelistrikan } \\
\text { dinamis yang valid, praktis, dan efektif untuk merangsang berpikir kritis } \\
\text { siswa. Model pengembangan menggunakan model ADDIE yang terdiri } \\
\text { dari langkah-langkah analisis, desain, pengembangan, implementasi, dan } \\
\text { evaluasi. Produk yang dikembangkan diuji validasi, uji kepraktisan, dan } \\
\text { uji keefektifan. Hasil uji validitas diperoleh nilai } 81,80 \% \text { dengan kategori } \\
\text { valid. Hasil uji kepraktisan diperoleh persentase sebesar } 80,85 \% \text { dengan } \\
\text { kriteria baik. Hasil uji efektivitas menunjukkan nilai N-Gain sebesar } 0,67 \\
\text { dengan kategori cukup efektif. Dari rata-rata nilai pretest dan posttest } \\
\text { terlihat bahwa nilai rata-rata posttest meningkat sebesar } 39,04 \text { yang } \\
\text { menunjukkan bahwa penggunaan LKS berbasis AR dapat meningkatkan } \\
\text { berpikir kritis siswa. Dapat disimpulkan bahwa LKS berbasis AR konsep } \\
\text { listrik dinamis yang dikembangkan valid, praktis, dan efektif untuk } \\
\text { merangsang berpikir kritis siswa. }\end{array}$ \\
\hline
\end{tabular}




\section{INTRODUCTION}

The influence of the rapid development of information technology cannot be avoided by education. Global demands require education to constantly adapt to technological developments as an effort to improve the quality of education, especially adjusting the use of information technology in the learning process. Technological developments encourage education to increase innovation and creativity in the learning process. Providing quality learning by following technological developments will increase success in the classroom [1].

Utilization of information and communication technology in education is currently one of the factors in supporting the success of a learning process. Teachers must be technology literate in order to provide good information to students. Teachers must be able to act as facilitators for students, especially in the use of various learning resources so that teaching and learning activities are more effective, efficient, and not monotonous. [2],[3],[4].

One of the technologies that are developing in the field of education today is Augmented Reality (AR). AR allows users to see 3D virtual objects added to the real environment. How does AR work? AR reads a marker in the form of an image and will be detected by a smartphone camera, the camera will detect the marker and then display it in the form of 3D animation or video, if the marker is recognized and in accordance with the database that was created previously. So, in the end, the real object will merge with the virtual object in the final view of the application [5]. AR allows computergenerated virtual objects to be placed on physical objects in real time [6]. AR technology can contain video, sound, photos, text, 3D models [7],[8]. AR offers new ways to interact with the physical world and is changing the way people learn with mobile devices [9].

Several AR developments in education have been carried out. This AR technology can help teachers and students visualize objects with an application containing object animation demonstrations that support learning materials [10],[5]. Most of the research conducted on AR to date shows that students are excited and interested in learning to use this technology. The results showed that the use of AR technology in mathematics lessons increased student achievement and motivation [11]. AR also makes students more active in the learning process because of the interactivity of the application [12].

The advantage of AR technology is that it can be widely implemented in various media, such as smartphones, cards, books, magazines, or Student Activity Sheets. Several AR studies in education have implemented AR with card media. This makes it difficult for students to use AR applications independently. To facilitate the use of AR can be implemented with a student worksheet. Thus, AR applications combined with student worksheets can be presented coherently and can be used independently.

Student worksheet is a printed teaching material in the form of sheets containing reading material, summaries, and instructions for implementing learning tasks that must be done by students referring to the basic competencies that must be achieved [13]. The use of worksheets in learning can encourage students to process the material being studied, either independently or in groups. However, the worksheets used in schools today are still limited to conventional worksheets, worksheets made by publishers that are ready to use, without any effort to plan, prepare, and compile by the teacher. [13]. Summary of material, questions, guidance, and assignments in conventional student worksheets are not suitable for students' needs and are not contextual, so they are not able to increase student competence optimally. The worksheets used today only serve to present concept/theory test materials, do not provide questions that train students to think critically. The use of teaching materials by combining several media such as color images, animations, videos 
and so on will attract students to learn [14]. In addition, the use of different multimedia variations (text, images, animation, and video) can improve critical thinking skills [15].

Critical thinking skills need to be developed in students because it has become a 21 st century human need. Through critical thinking skills students can more easily understand concepts, be able to apply concepts to different situations, and be more sensitive to problems. Critical thinking is a reasoned and reflective way of thinking with an emphasis on making decisions about what to believe or do [16]. Critical thinking skills can be developed through active and student-centered learning. However, in general, the physics learning process in schools is still teacher centered, and usually, teachers focus more on improving cognitive knowledge and not explaining concepts, so that students do not use their critical thinking skills in the learning process.

Based on the results of observations made at SMP Negeri 2 Rawa Pitu, Tulang Bawang Regency, the worksheets used in schools are conventional worksheets. In the theory section, only formulas and brief theories are written, so as not to provoke students' curiosity to apply them in everyday life. Writing formulas directly also causes students to become unfamiliar in solving problems related to theory. In the design section, the paper used is opaque, and the images are 2-dimensional and colorless (black and white) so that they are less attractive to students.

In addition, the available worksheets also do not have a specific model syntax or approach so that they cannot train students' critical thinking abilities and skills. The worksheets used are not specific to one learning model. In this case, the author develops a more specific worksheet using the Guided Inquiry learning model. Inquiry learning is one of the effective ways that can help students to improve their thinking skills by using higher mental processes and critical thinking skills [17]. Through inquiry learning, students' critical thinking skills can develop well.

The physics concept chosen in this research is dynamic electric matter. Dynamic electricity is one of the physics concepts that have many links with students' everyday phenomena. This concept was chosen because dynamic electrical phenomena are difficult to imagine. So it requires media that can present dynamic electrical phenomena. Phenomena related to the concept of dynamic electricity can be displayed in 3D animation and video using AR technology, making it easier for students to understand concepts and build motivation to learn Physics [18].

Based on the description stated above, it is necessary to develop a Student Worksheet based on Augmented Reality (AR) on the concept of dynamic electricity to stimulate students' critical thinking. This development research is important to do based on a literature study on the use of AR media which proved that AR media have a significant influence and can improve students' critical thinking skills [19]. The purpose of this study is to develop an AR-based worksheet on dynamic electrical material that is valid, practical, and effective to stimulate students' critical thinking.

\section{METHOD}

In a development research, a development method is needed to test the resulting product. This research was carried out during the pandemic on 9th grade students of SMP Negeri 2 Rawa Pitu, totaling 26 people consisting of 8 male students and 18 female students. Data collection techniques in this study were obtained through questionnaires, validation sheets, observation sheets, and tests. 
The research and development method is a research method used to produce a particular product and test the effectiveness of the product [20]. The model used is the ADDIE model: Analysis, Design, Development, Implementation, and Evaluation which is carried out in a systematic stage. The process of this research can be seen in Figure 1.

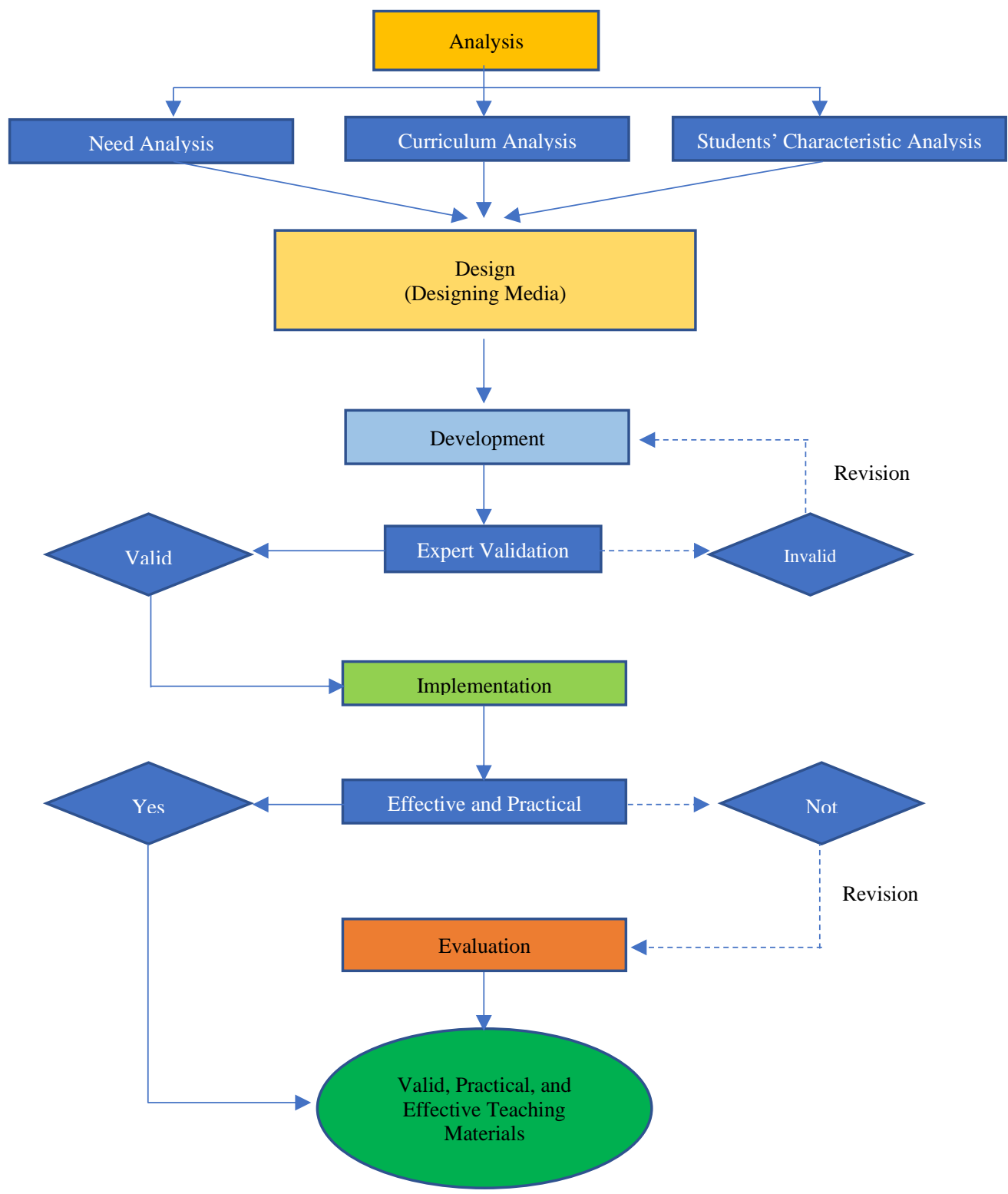

Figure 1. Research and Development Design Flowchart

\subsection{Analysis}

The analysis stage is the stage where researchers analyzed the needs of students and teachers related to the development of teaching materials and analyze the feasibility and development requirements. The analysis stage includes three things: Analyzing the availability of teaching materials and the use of teaching materials as the main information in learning. Analyze the curriculum that is being used in schools. Analyzing the character of students to see students' attitudes towards science learning. This stage needs to be done so that the development of teaching materials is in accordance with the character of students. 


\subsection{Design}

The second stage of the ADDIE model is the design stage. At this stage, a worksheet is designed based on a needs analysis. Next, the design stage is carried out by determining the content contained in the worksheet, such as the preparation of a needs map, and the worksheet framework. The researcher also collects the references used in developing the material in the worksheet. At this stage, the researcher also developed an instrument that would be used to assess the developed worksheet. The instrument is prepared by taking into account the aspects of the worksheet such as aspects of content feasibility, language feasibility, presentation feasibility, graphic feasibility, and suitability with the approach used. The instruments arranged are in the form of assessment sheets and response questionnaires. Furthermore, the instrument was validated to obtain a valid assessment instrument.

\subsection{Development}

The development stage is the product realization stage. At this stage, the development of the worksheet is carried out according to the design. After the worksheet is ready, a validation test is carried out by lecturers and teachers. In the validation process, the validator used the instruments that have been prepared in the previous stage. Validation was carried out by 3 validators, media expert validator, content expert validator, and science subject expert validator. The media expert validator is a lecturer who has specifications in the media field. A content expert validator is a lecturer who has specific expertise on the topic being developed. And the validator of science learning experts is a science subject teacher in the field of physics. At this stage, the researcher also analyzes the data on the results of the validation worksheet from the validator. This is done to get the value of student worksheet validity.

\subsection{Implementation (Implementasi)}

Implementation is limited to the school where the research is conducted. The teacher conducts learning with the help of a worksheet that has been developed. After the learning process is complete, students take a test using the questions that have been provided. At this stage, the researchers also distributed student response assessment sheets containing statements about the use of worksheet in learning. This is done to obtain data related to the practical value of using the worksheet. Moreover, students were also asked to provide comments as a reference for the second revision according to student responses. The media effectiveness test in the individual test and small group test is the One-Group PretestPosttest Design, which consists of one experimental group without a control group [21]. This design compares the value of working on questions to measure critical thinking after using the worksheet

\subsection{Evaluation (Evaluasi)}

At this stage the researcher made a final revision of the developed worksheet based on the input obtained from the response questionnaire or field notes on the observation sheet. This is so that the worksheets developed are truly appropriate and can be used more widely.

\section{RESULTS AND DISCUSSION}

This research and development produced an Augmented Reality (AR)-based student worksheet. The AR-based student worksheet was developed in stages: analysis, carried out in three parts, needs analysis by analyzing the state of teaching materials as the main 
information in learning and the availability of teaching materials that support the implementation of a lesson. The teaching materials used are textbooks and conventional student worksheets. The existing student worksheet is less attractive because it contains 2D and black and white images. Moreover, students want a student worksheet that contains material, pictures, videos, animations, and practice questions. The use of multimedia variations can improve critical thinking skills [15]. The use of multimedia in improving students' critical thinking skills can be optimized if it is combined with the right learning model [22]. The use of smartphones in learning is not optimal. Students use smartphones more often to play games and social media than to study. AR is one of the new technologies that is growing rapidly and popular today. AR technology can contain video, sound, photos, text, and 3D models [7], [8]. The use of AR technology in learning allows students to explore the world interactively and collaboratively [23]. AR-based interactive multimedia provides 3D interaction facilities with users, by utilizing AR technology, allowing students to more easily see an overview of a concept [23]. Curriculum analysis was carried out by analyzing the characteristics of the curriculum that is being applied in a school. The curriculum used in schools is the 2013 curriculum. Student character analysis is carried out to see students' attitudes towards science learning. Students prefer to learn science by watching videos of phenomena and their application in daily life by using smartphones.

The Design stage is the stage for designing Augmented Reality-based student worksheets. The initial design of the product includes a student worksheet cover that is made as attractive as possible, describes the contents of the student worksheet, and displays the student worksheet identity and student identity to foster students' critical thinking skills and components related to the student worksheet. The parts of the design on the student worksheet are as follows:

Table 1. Student Worksheet Design

\begin{tabular}{cccc}
\hline No Aspect & \multicolumn{1}{c}{ Information } \\
\hline 1 Cover & $\begin{array}{l}\text { The picture on the right is the front } \\
\text { cover design of the module. The } \\
\text { description of the picture is: } \\
\text { Title, author's name, picture } \\
\text { according to concept, AR marker, } \\
\text { class, and student name column }\end{array}$
\end{tabular}




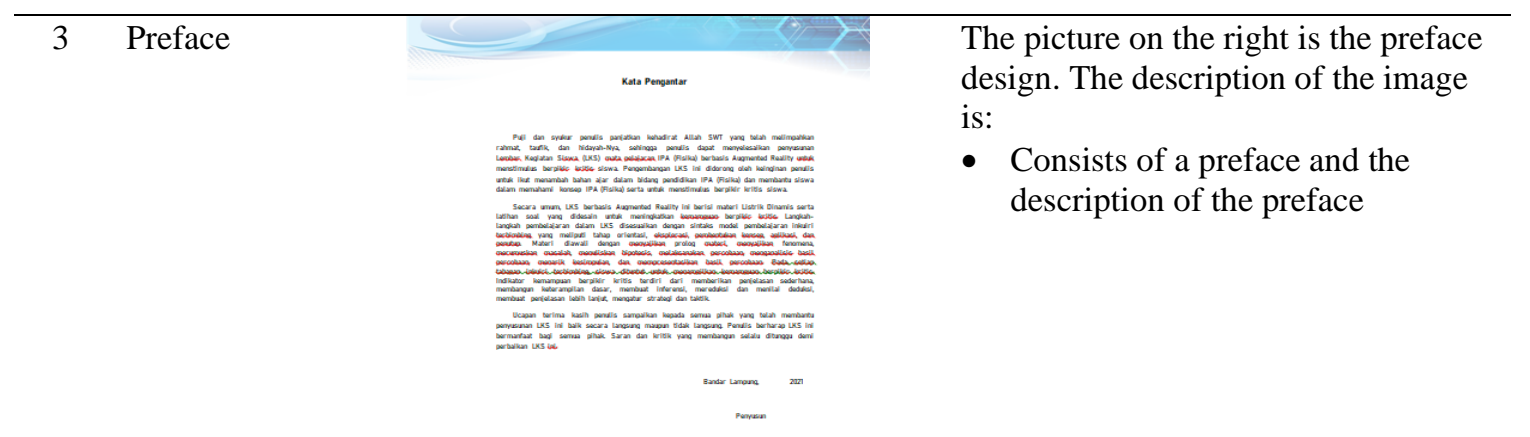

4 Core and

Basic

Competences

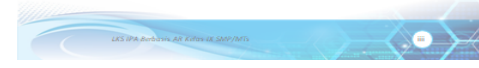

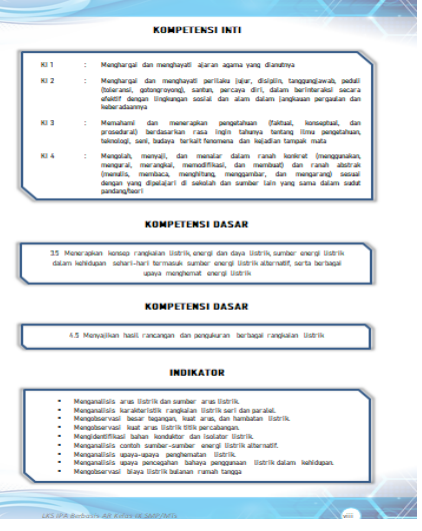

5 Outline

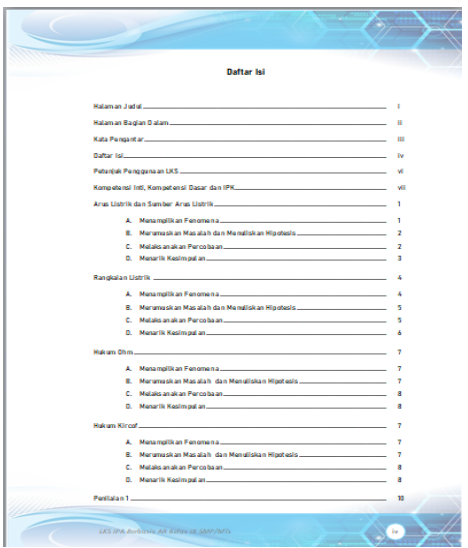

6 Instructions

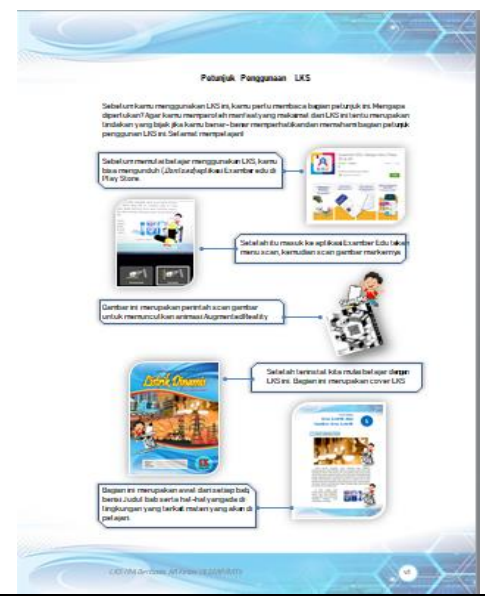

Is the third page design in the form of standard content. The explanation of the picture is:

- Consists of core competencies, basic competencies, and indicators.

Consists of a table of contents and a description of the content on the student worksheet

Contains instructions for using this worksheet. 


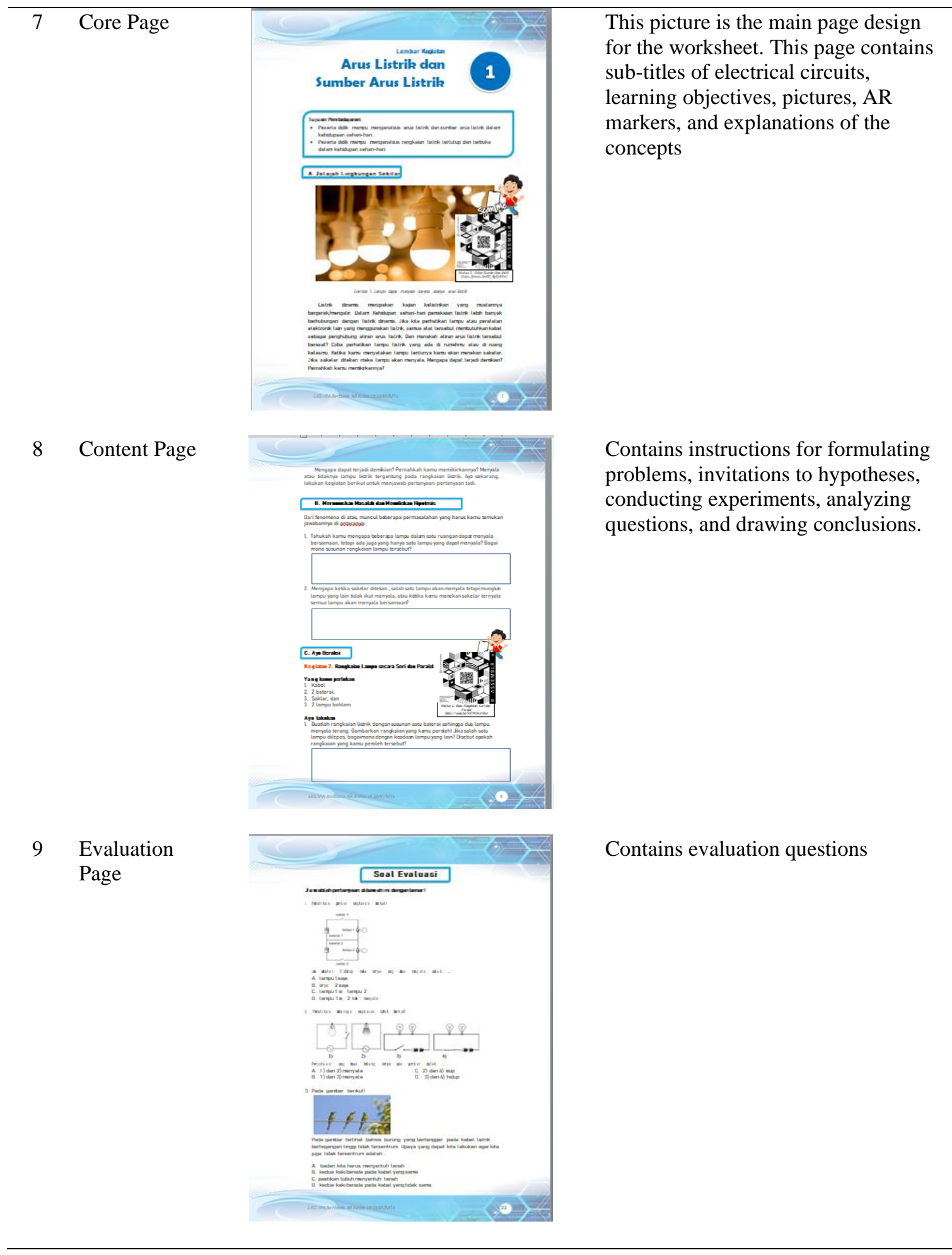

AR development in this study used the Assemblr Studio application. Assemblr is an application that can help create interactive designs quickly, easily, and fun. With the help of AR technology, we can create 3D designs complete with photos, videos, and text. Assemblr can be the platform of choice for all your design needs, from 3D posters, flyers, catalogs, greeting cards, business cards, picture books, invitations, packaging, and more. An example of the AR design process with Assemblr Studio can be seen in Figure 2. 


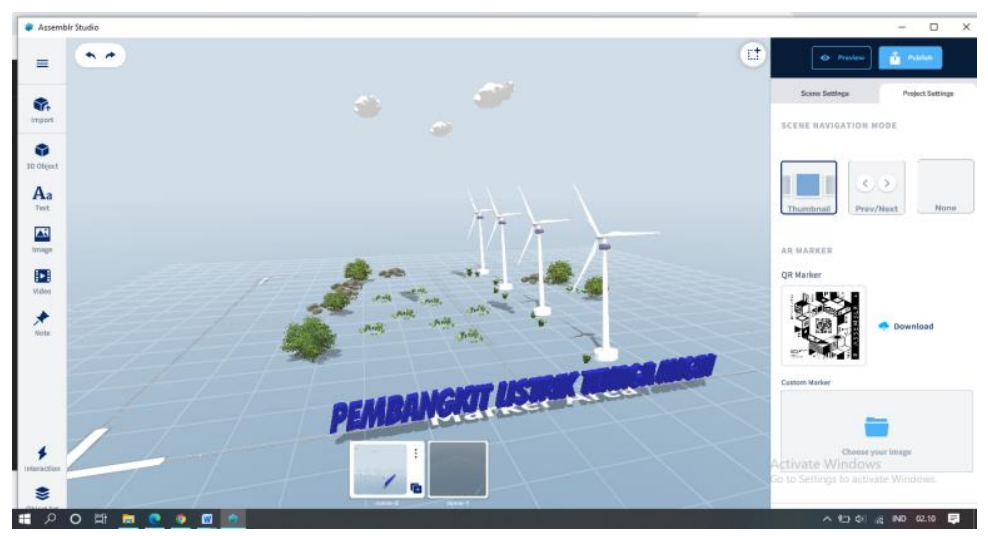

Figure 2. AR Design Process Using Assemblr Studio

The result of making AR is in the form of a marker which is then scanned using the assembler or assemblr edu application installed on the smartphone. Figure 3 shows the results of an AR marker scan with a smartphone
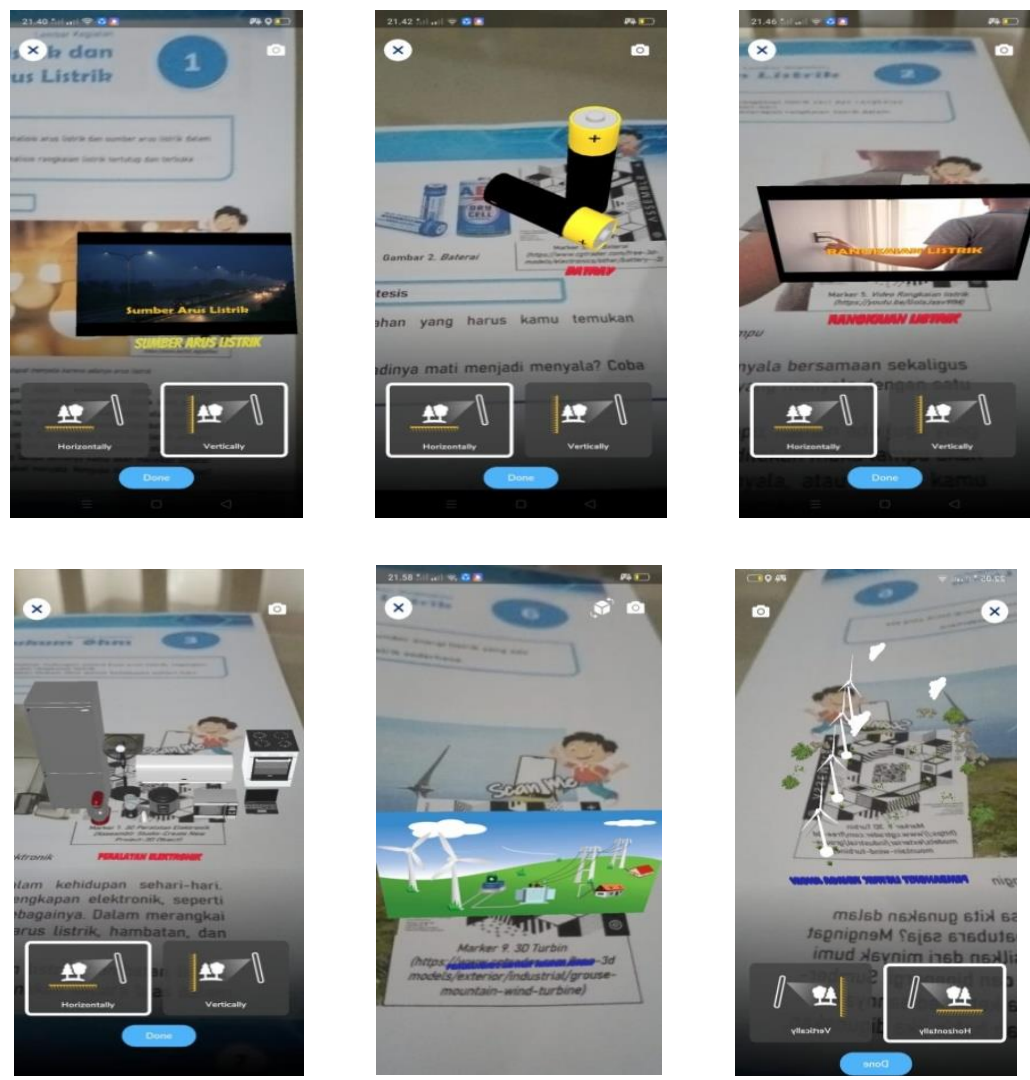

Figure 3. The Process of Scanning AR Markers with a Smartphone

The development stage includes testing the validity of the designed AR-based student worksheet. The validity test consists of testing the validity of media experts, the validity of content experts, and testing the validity of learning experts. The following is the data from the AR-based worksheet validity test results: 


\subsection{Validation Results}

Before being tested on students, this worksheet was validated by media experts, content experts, and learning experts to determine the feasibility of the product development. From the results of this expert assessment, it is known the level of validity of the student worksheet.

The results of the validator assessment in detail are shown in Table 2.

Table 2. AR-Based Student Worksheet Media Validation Results

\begin{tabular}{ccc}
\hline Aspect & Score & Percentage \\
\hline Worksheet Size & 4,00 & $80,00 \%$ \\
Cover Design & 4,00 & $80,00 \%$ \\
Content Design & 3,82 & $76,40 \%$ \\
3D Drawing Design & 4,00 & $80,00 \%$ \\
Video Design & 4,33 & $86,60 \%$ \\
AR media & 4,25 & $85,00 \%$ \\
Learning Process & 4,00 & $80,00 \%$ \\
Average & 4,06 & $81,14 \%$ \\
\hline
\end{tabular}

The results of the AR-based student worksheet validation show that this worksheet is valid for use with a percentage of $81.14 \%$. Furthermore, the data from the content expert validation can be seen in Table 3 .

Table 3. AR-Based Student Content Validation Results

\begin{tabular}{ccc}
\hline Aspect & Score & Percentage \\
\hline Content Eligibility & 3,87 & $77,39 \%$ \\
Serving Eligibility & 3,86 & $77,14 \%$ \\
Language & 4,08 & $81,67 \%$ \\
Average & 3,94 & $78,73 \%$ \\
\hline
\end{tabular}

The results of the AR-based worksheet content validation show that this worksheet is valid for use with a percentage of $78.73 \%$. Furthermore, the data from the validation of learning experts can be seen in Table 4.

Table 4. AR-Based Student Learning Validation Results

\begin{tabular}{ccc}
\hline Aspect & Score & Percentage \\
\hline Quality, satisfaction, usability & 4,50 & $90,00 \%$ \\
Novelty & 4,33 & $86,60 \%$ \\
Individual impact & 4,25 & $85,00 \%$ \\
Average & 4,28 & $85,53 \%$ \\
\hline
\end{tabular}

The results of the validation of aspects of quality, novelty, and individual impact showed an average percentage of $85.53 \%$ with very valid criteria for use in learning.

Implementation phase includes practicality test and AR-based student worksheet effectiveness test. The following is the data from the practicality test and the effectiveness test of the AR-based student worksheet.

\subsection{Practicality Test Results}

The data obtained from the results of the student response assessment sheets were then analyzed quantitatively to determine the practicality of the product. The data from the practicality test can be seen in Table 5 . 
Table 5. AR-based Student Worksheet Practicality Test Results

\begin{tabular}{ccc}
\hline Aspect & Score & Percentage \\
\hline Ease of Use & 3,98 & $79,62 \%$ \\
Attractiveness & 4,00 & $80,00 \%$ \\
Efficiency & 4,05 & $81,08 \%$ \\
Usability & 4,12 & $82,31 \%$ \\
Average & 4,04 & $80,75 \%$
\end{tabular}

The results of the practicality test of AR-based student worksheets are $80.75 \%$, so the overall average percentage of all aspects of the AR-based student worksheet practicality assessment is in good criteria.

\subsection{Effectiveness Test Results}

The media effectiveness test in the individual test was the One-Group PretestPosttest Design, which consisted of an experimental group without a control group. PreTest and Post-Test result data can be seen in Table 6 below.

Table 6. Pre-Test and Post-Test Results

\begin{tabular}{|c|c|c|c|c|c|c|}
\hline No & Name & $\begin{array}{c}\text { Pre-Test } \\
\text { Score }\end{array}$ & $\begin{array}{l}\text { Post-Test } \\
\text { Score }\end{array}$ & Difference & $\begin{array}{l}\text { Gain } \\
\text { Index }\end{array}$ & Criteria \\
\hline 1 & Student 1 & 30 & 80 & 50 & 0,71 & Effective \\
\hline 2 & Student 2 & 40 & 75 & 35 & 0,58 & Moderately Effective \\
\hline 3 & Student 3 & 45 & 70 & 25 & 0,45 & Moderately Effective \\
\hline 4 & Student 4 & 45 & 85 & 40 & 0,73 & Effective \\
\hline 5 & Student 5 & 25 & 75 & 50 & 0,67 & Moderately Effective \\
\hline 6 & Student 6 & 25 & 80 & 55 & 0,73 & Effective \\
\hline 7 & Student 7 & 20 & 75 & 55 & 0,69 & Moderately Effective \\
\hline 8 & Student 8 & 35 & 50 & 15 & 0,23 & Somewhat Effective \\
\hline 9 & Student 9 & 30 & 80 & 50 & 0,71 & Effective \\
\hline 10 & Student 10 & 75 & 95 & 20 & 0,80 & Effective \\
\hline 11 & Student 11 & 30 & 75 & 45 & 0,64 & Moderately Effective \\
\hline 12 & Student 12 & 25 & 65 & 40 & 0,53 & Moderately Effective \\
\hline 13 & Student 13 & 40 & 85 & 45 & 0,75 & Effective \\
\hline 14 & Student 14 & 40 & 80 & 40 & 0,67 & Moderately Effective \\
\hline 15 & Student 15 & 20 & 75 & 55 & 0,69 & Moderately Effective \\
\hline 16 & Student 16 & 40 & 70 & 30 & 0,50 & Moderately Effective \\
\hline 17 & Student 17 & 35 & 80 & 45 & 0,69 & Moderately Effective \\
\hline 18 & Student 18 & 50 & 85 & 35 & 0,70 & Effective \\
\hline 19 & Student 19 & 40 & 75 & 35 & 0,58 & Moderately Effective \\
\hline 20 & Student 20 & 30 & 75 & 45 & 0,64 & Moderately Effective \\
\hline 21 & Student 21 & 45 & 85 & 40 & 0,73 & Effective \\
\hline 22 & Student 22 & 50 & 75 & 25 & 0,50 & Moderately Effective \\
\hline 23 & Student 23 & 35 & 75 & 40 & 0,62 & Moderately Effective \\
\hline 24 & Student 24 & 35 & 70 & 35 & 0,54 & Moderately Effective \\
\hline 25 & Student 25 & 45 & 75 & 30 & 0,55 & Moderately Effective \\
\hline 26 & Student 26 & 35 & 70 & 35 & 0,54 & Moderately Effective \\
\hline \multicolumn{2}{|c|}{ Average } & 37,12 & 76,15 & 39,04 & 0,62 & Moderately Effective \\
\hline \multicolumn{2}{|c|}{ Max. Score } & 75 & 95 & 55 & 0,80 & - \\
\hline \multicolumn{2}{|c|}{ Min. Score } & 20 & 50 & 15 & 0,23 & - \\
\hline
\end{tabular}


The Pre-Test results showed an average score of 37.12 with the highest score of 75 and the lowest score of 20. Meanwhile, the Post-Test results showed an average score of 76.15 with the highest score of 95 and the lowest score of 50.

The data from the Pre-Test and Post-Test results were then processed to test the effectiveness of AR-based student worksheets. The data on the results of the effectiveness test can be seen in Table 7 below.

Table 7. AR-based Student Worksheet Effectiveness Results

\begin{tabular}{ccccccc}
\hline \multirow{2}{*}{ Class } & \multirow{2}{*}{ N } & \multicolumn{4}{c}{ Average } & \multirow{2}{*}{ Category } \\
\cline { 3 - 6 } & & Pretest & Posttest & Gain & N-Gain & Moderately Effective \\
\hline IX & 26 & 37,12 & 76,15 & 39,04 & 0,62 & \multirow{2}{*}{. } \\
\hline
\end{tabular}

The results of the AR-based student worksheet effectiveness test showed an N-Gain value of 0.62 so that according to the media effectiveness test data, the overall average percentage of all aspects stated that AR-based student worksheets were moderately effective.

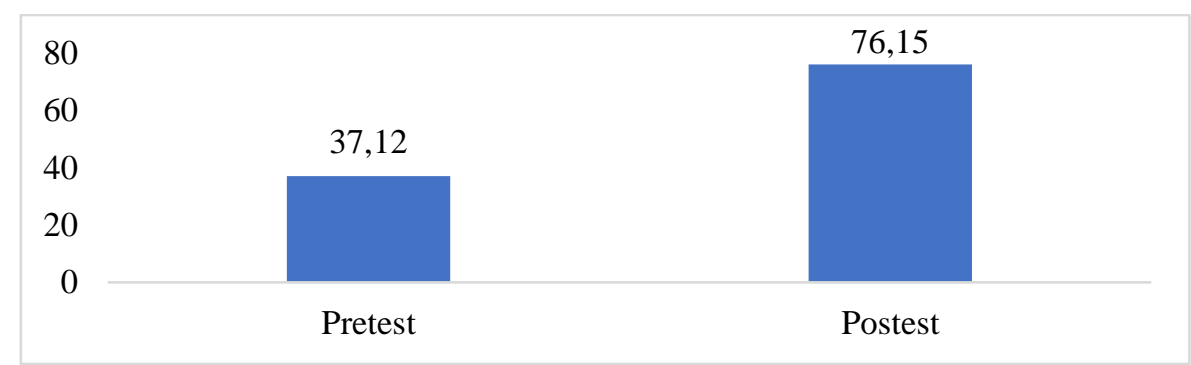

Figure 4. The Average Result of Students' Critical Thinking Skills

Figure 4 shows that the students' prior critical thinking skills, which are seen from the average pretest score of 37.12, have not yet reached the minimum school criteria score. Meanwhile, the students' posttest results showed an increase in critical thinking skills with an average score of 76.15. This shows that the use of AR-based student worksheet can improve students' critical thinking skills.

The results of the media expert validation data analysis showed that the AR-based student worksheet was valid with an ideal percentage of $81.80 \%$. Validation data from content experts shows that AR-based student worksheets get a valid category with an ideal percentage of $78.73 \%$. And based on the results of the validation test, the learning expert stated that this worksheet was very Grade 9 e with a percentage of $85.53 \%$. From the three aspects of validity, an average validation value of $81.80 \%$ is obtained, which is included in the valid category. The requirements for a good instrument that can be applied in learning are that the instrument must be valid from the content aspect and constructively valid [24]. And the validity of product designs by experts is assessed from several aspects, one of which is the construction aspect [25]. Therefore, it can be concluded that this ARbased student worksheet can be used in science learning in junior high school.

The practicality test was obtained from the student opinion test which contained student responses related to the ease, attractiveness, efficiency, and benefits of the worksheet. A multimedia is said to be practical if users (teachers and students) feel that this multimedia is easy and effective to use [26]. The results of practicality data analysis show that this AR-based student worksheet got a percentage of $80.75 \%$ in the practical category. These results indicate that AR-based worksheets are very easy to use by students. This AR-based student worksheet uses language that is easy for students to understand, and videos and 2D and 3D images can be accessed easily. The practicality of learning 
media is important to know because one of the important points for choosing a good learning media is the ease of use. [27].

The results of the effectiveness test obtained from the pretest and posttest data showed an N-Gain value of 0.67 with a moderately effective category for use in the science learning process in junior high school. The amount of the achievement value shows a moderate classification with a moderately effective level of effectiveness [28]. Students are more enthusiastic in the learning process with AR-based worksheets because of the display of 3D images and videos.
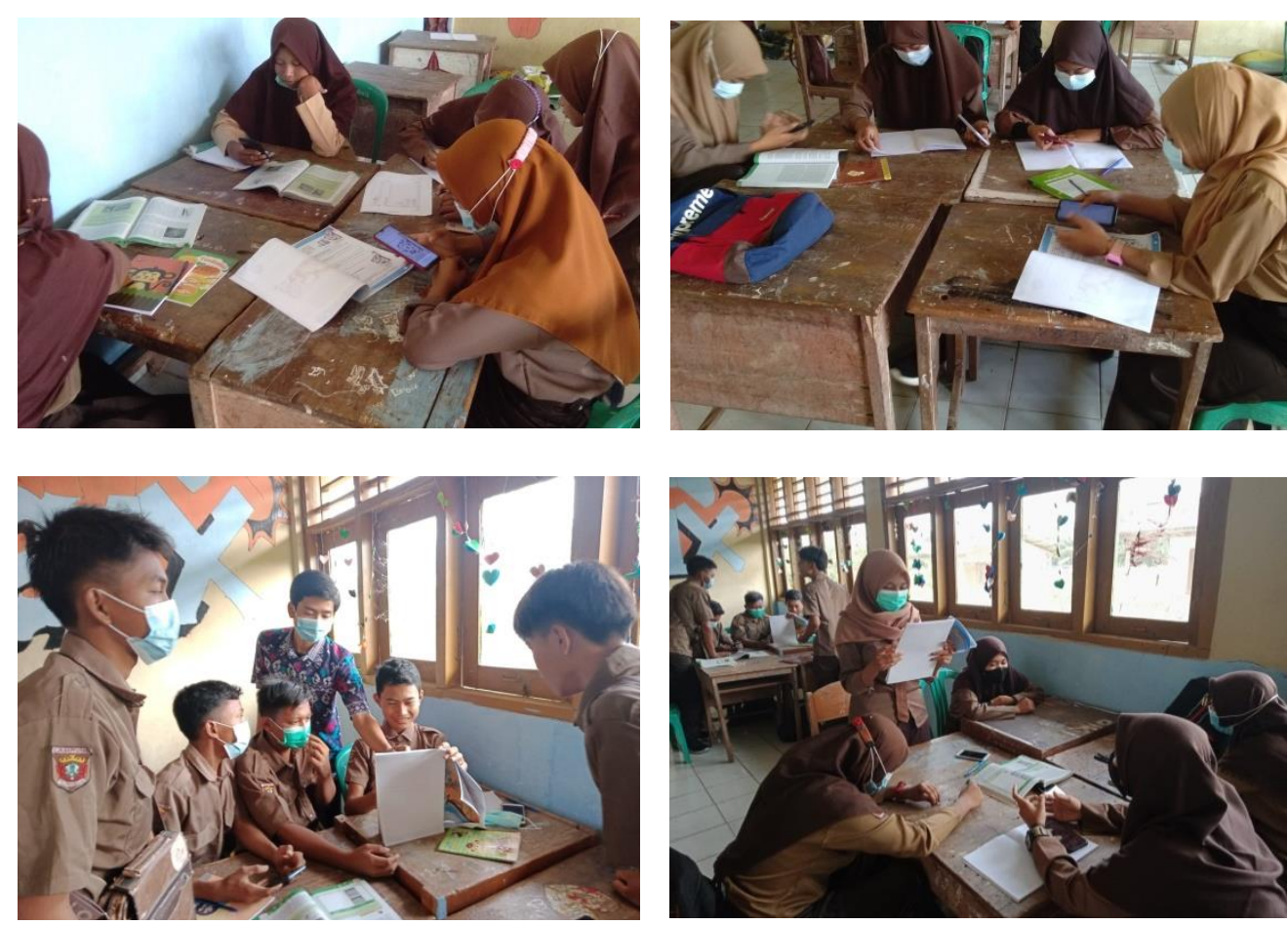

Figure 5. Learning Activities

The posttest results show an increase in the average score of 39.04 which indicates that the use of AR-based worksheets can improve students' critical thinking skills in junior high school. AR-based student worksheets are arranged systematically to direct students in the learning process. In addition, this AR-based worksheet is also equipped with 2D images, 3D images, and videos. This can help stimulate students' critical thinking skills so that students are more enthusiastic and interested in learning. AR models assist with dynamic building and motivational processes by increasing task control and promoting collaborative learning [29]. Besides increasing motivation and satisfaction, AR-based worksheet also increases student engagement in learning, in which engagement is an important dimension that affects learning outcomes. Student involvement in learning is also important to train students' higher-order thinking skills such as problem-solving, critical or creative thinking that can be supported by AR applications [30]. The use of several media in the learning process can increase interest and train students' critical thinking. The use of different multimedia variations can improve critical thinking skills [15]. Previous research has proven that the use of AR media can improve thinking skills and attitudes towards algebra [31]. The use of AR media has a significant influence and is able to improve students' critical thinking skills [19]. 


\section{CONCLUSION}

Based on the data that has been collected, it is proven that the AR-based student worksheet on dynamic electricity is valid and feasible to use in learning. The results of the validity test show the percentage of $81.80 \%$ with valid criteria. The results of the student response test also showed a percentage result of $80.75 \%$ in the practical category, this indicates that this worksheet can be easily used in the learning process. This worksheet is also proven to be able to stimulate critical thinking, this is evidenced by the N-Gain value of 0.67 which is in the criteria of being quite effective. This AR-based worksheet is effective in improving students' critical thinking skills because it has a series of activities including: displaying phenomena, formulating problems and writing hypotheses, carrying out experiments, drawing conclusions and there are AR markers containing 3D images and videos that can be scanned using a smartphone.

\section{REFERENCES}

[1] D. Ünlü, “Technology in education,” Turkish Online J. Educ. Technol., vol. 2016, no. july, 2016, doi: 10.4135/9781452204741.n2.

[2] V. Chandra and J. J. Watters, "Re-thinking physics teaching with web-based learning," Comput. Educ., vol. 58, no. 1, 2012, doi: 10.1016/j.compedu.2011.09.010.

[3] T. J. Wu and Y. N. Tai, "Effects of multimedia information technology integrated Multi-Sensory instruction on students' learning motivation and outcome," Eurasia J. Math. Sci. Technol. Educ., vol. 12, no. 4, 2016, doi: 10.12973/eurasia.2016.1552a.

[4] G. Muhametjanova and A. Akmatbekova, "The web-based learning environment in general physics course in a public university in Kyrgyzstan," Eurasia J. Math. Sci. Technol. Educ., vol. 15, no. 3, 2019, doi: 10.29333/ejmste/100409.

[5] D. Bogusevschi, C. H. Muntean, and G.-M. Muntean, "Teaching and Learning Physics using 3D Virtual Learning Environment: A Case Study of Combined Virtual Reality and Virtual Laboratory in Secondary School.," J. Comput. Math. Sci. Teach., vol. 39, no. 1, 2020.

[6] M. Ozdemir, C. Sahin, S. Arcagok, and M. K. Demir, "Eurasian Journal of Educational Research The Effect of Augmented Reality Applications in the Learning Process: A Meta-Analysis Study *," Eurasian J. Educ. Res., vol. 74, 2018.

[7] H. Tekedere and H. Göker, "Examining the effectiveness of augmented reality applications in education: A meta-analysis," Int. J. Environ. Sci. Educ., vol. 11, no. 16, 2016.

[8] S. Liang and C. Roast, "Five Features for Modeling Augmented Reality," in Communications in Computer and Information Science, 2014, vol. 434 PART I, doi: 10.1007/978-3-319-07857-1_107.

[9] D. R. R. Joan, "Enhancing Education through Mobile Augmented Reality," $i$ manager's J. Educ. Technol., vol. 11, no. 4, pp. 8-14, 2015, doi: 10.26634/jet.11.4.3147.

[10] S. Cai, F. K. Chiang, Y. Sun, C. Lin, and J. J. Lee, "Applications of augmented reality-based natural interactive learning in magnetic field instruction," Interact. Learn. Environ., vol. 25, no. 6, 2017, doi: 10.1080/10494820.2016.1181094.

[11] A. Estapa and L. Nadolny, "The Effect of an Augmented Reality Enhanced Mathematics Lesson on Student Achievement and Motivation," J. STEM Educ., vol. 16, no. 3, 2015.

[12] A. A. and A. S. E. Lamounier, A. Bucioli, A. Cardoso, "On the use of Augmented 
Reality techniques in learning and interpretation of cardiologic data," 2010 Annu. Int. Conf. IEEE Eng. Med. Biol., no. IEMBS.2010.5628019., pp. 610-613, 2010, doi: 10.1109 .

[13] P. Andi, Prastowo, A. (2013). Panduan Kreatif Membuat Bahan Ajar Inovatif. Yogyakarta: Diva Press. Yogyakarta: DIVA press, 2011.

[14] Khoiriah, T. Jalmo, and Abdurrahman, "The effect of multimedia-based teaching materials in science toward students' cognitive improvement," J. Pendidik. IPA Indones., vol. 5, no. 1, 2016, doi: 10.15294/jpii.v5i1.5793.

[15] Z. M. Zulkifli Mariana; Sari, Ermina, "Peningkatan Keterampilan Berpikir Kritis Sebagai Pembentuk Karakter Calon Guru Biologi Pada 3 Varian Multimedia Yang Berbeda," Pros. Semin. Biol., no. Vol 8, No 1 (2011): Seminar Nasional VIII Pendidikan Biologi, 2011.

[16] H. Reeder, "The Nature of Critical Thinking," Informal Log., vol. 6, no. 2, pp. 1-8, 1984, doi: 10.22329/il.v6i2.2729.

[17] D. K. Paul Eggen, Strategic and models or teachers: Teaching content and thinking skills, Ed. ke 6,. Jakarta: Indeks, 2012.

[18] M. Fidan and M. Tuncel, "Integrating augmented reality into problem based learning: The effects on learning achievement and attitude in physics education," Comput. Educ., vol. 142, 2019, doi: 10.1016/j.compedu.2019.103635.

[19] T. A. Retnaningtiyas, N. Suprapto, and H. R. Achmadi, "Studi Literatur Pemanfaatan Media Augmented Reality Untuk Meningkatkan Keterampilan Berpikir Kritis Peserta Didik Tiya Ayu Retnaningtiyas, Nadi Suprapto , Hainur Rasid Achmadi Tiya Ayu Retnaningtiyas , Nadi Suprapto , Hainur Rasid Achmadi Tiya Ayu Retnan," vol. 10, no. 01, pp. 39-49, 2021.

[20] Sugiyono, Metode Penelitian Pendidikan Pendekatan Kuantitatif, Kualitatif dan RnD. Bandung: Alfabeta, 2008.

[21] A. Suyatna, Uji Statistik Berbantu SPSS untuk Penelitian Pendidikan. Yogyakarta: Media akademi, 2017.

[22] P. Giavrimis, E. Papanis, and E.-M. Papanis, "Information and Communication Technologies and Development of Learners' Critical Thinking: Primary School Teachers' Attitudes," Int. Educ. Stud., vol. 4, no. 3, pp. 150-160, 2011, doi: 10.5539/ies.v4n3p150.

[23] J. Martín-Gutiérrez, J. Luís Saorín, M. Contero, M. Alcañiz, D. C. Pérez-López, and M. Ortega, "Design and validation of an augmented book for spatial abilities development in engineering students," Comput. Graph., vol. 34, no. 1, 2010, doi: 10.1016/j.cag.2009.11.003.

[24] E. Wijayanti and M. Mundilarto, "Pengembangan Instrumen Asesmen Diri Dan Teman Sejawat Kompetensi Bidang Studi Pada Mahasiswa," J. Penelit. dan Eval. Pendidik., vol. 19, no. 2, 2015, doi: 10.21831/pep.v19i2.5572.

[25] R. Wusqo, I.U., Taufiq,M., Handayani, "Pengembangan Asesmen Alternatif Praktikum Kimia Dasar Ii Melalui Chemistry Fair Project (Cfp) Berbasis Konservasi Dengan Memanfaatkan Daily Chemical," J. Penelit. Pendidik., vol. 33, no. 2, 2016, doi: 10.15294/jpp.v33i2.9096.

[26] T. Akbar, "Pengembangan Multimedia Interaktif Ipa Berorientasi Guided Inquiry Pada Materi Sistem Pernapasan Manusia Kelas V Sdn Kebonsari 3 Malang," J. Pendidik. - Teor. Penelitian, dan Pengemb., vol. 1, no. 6, 2016, doi: 10.17977/jp.v1i6.6456.

[27] W. Saputra and B. E. Purnama, "Pengembangan multimedia pembelajaran interaktif untuk mata kuliah organisasi komputer," Speed-Sentra Penelit. Eng. dan ..., 2015. 
[28] R. R. Hake, "Analyzing change/gain scores," Unpubl. URL http//www. physics. indiana. edu^ sdi/AnalyzingChange-Gain. pdf, vol. 16, no. 7, 1999.

[29] S. Fleck and G. Simon, "An augmented reality environment for astronomy learning in elementary grades: An exploratory study," 2013, doi: 10.1145/2534903.2534907.

[30] X. Wang, "Augmented Reality: A new way of augmented learning," eLearn, vol. 2012, no. 10, 2012, doi: 10.1145/2380716.2380717.

[31] A. S. Rahardjoni, I. N. Hasanah, and ..., "Developing critical thinking competence in algebraic thinking using augmented reality for junior high school," .. Nas. Mat., vol. 3, pp. 497-503, 2020, [Online]. Available: https://journal.unnes.ac.id/sju/index.php/prisma/article/view/37768. 